\title{
Design Thinking in the Postmodern Organization
}

\author{
Gürsel Ilipinar \\ ESADE Business School, Barcelona, Spain \\ Wesley J. Johnston \\ Georgia State University, Atlanta, USA \\ Jordi Montaña \\ ESADE Business School, Barcelona, Spain \\ John-Christopher (JC) Spender \\ Lund University, Lund, Sweden \\ Duane P. Truex \\ Georgia State University, Atlanta, USA
}

\begin{abstract}
Design discipline has been relatively slow to recognize the existence and impacts of postmodernism as compared to sociology, political science, marketing and management disciplines, however, recently postmodernist implications have begun to be explored by design scholars. Yet our review of the literature led us to conclude that the relationship between postmodernism and design thinking has received little, if any attention from design management scholars. The objective of this paper, then, is to expand the discussion on the relationship between postmodern organization and design thinking, to suggest strategic implications for design managers and research opportunities for management scholars.
\end{abstract}

Keywords: design, design thinking, management, postmodernism, postmodernity

\section{Introduction}

In the end, design is about shaping a context, rather than taking it as it is. When it comes to design, success arises not by emulating others, but by using organizational assets and integrative thinking to identify, build on, and leverage asymmetries, evolving unique models, products and experiences - in short, creative business solutions. (Roger Martin, The Design of Business, 2004)

Why do we find it congenial to speak of organizations as structures but not clouds, systems but not songs, weak or strong but not tender or passionate? Is it because organizations physically resemble one but not the other, that we somehow discern through the clamorous hurly burly something that is structural, but not cloudlike, systematic rather than rhapsodic, strong but not tender? (Parker, 1992, p. 1; Gergen, 1989, p. 1)

Gürsel Ilipinar, Ph.D. candidate, Department of Marketing, ESADE Business School.

Wesley J. Johnston. CBIM Roundtable Professor of Marketing, Department of Marketing, J. Mack Robinson College of Business, Georgia State University.

Jordi Montaña, Professor of Marketing and Design Management, Department of Marketing, ESADE Business School.

John-Christopher (JC) Spender, Svenska Handelsbanken Visiting Professor of Knowledge Management, Lund University.

Duane P. Truex, Institute of International Business, J. Mack Robinson College of Business, Georgia State University.

Correspondence concerning this article should be addressed to Gürsel Ilipinar, Department of Marketing, ESADE Business School, Av. Pedralbes, 60-62, E-08034, Barcelona, Spain. E-mail: gilipinar@yahoo.com. 
There is a quiet revolution going on in the business world! One influential domain within which the debates have been held is entitled "modernism versus postmodernism".

Modern business practices and the academic concepts behind such practices are struggling to cope with constantly technology-driven and culturally significant deconstructions and reconfigurations of markets, organizations and consumers (Dholakia \& Firat, 2006).

On the other hand, from the postmodern view of the organization, business is becoming the domain where all our adventures are experienced, acts are performed, creativity is flourished... "Yet in the public mind, business remains stubbornly linked to earning and spending, power and money. Can we redesign the businesses to reflect its (potentially) deeper reality being one of the most disruptive, free and creative forces of the postmodern world? Or is that a romantic pipe dream?" (Sauquet, 2008).

Even though we can observe its impacts on various aspects of life, postmodernism is still not well understood by many circles, and this often introduces tension and resistance (Firat, 1992). Despite its academic and popular opponents, postmodernist insights and ideas seem to be receiving growing attention and creating serious interest across many disciplines, including architecture, philosophy, literary criticism, women's studies, history, marketing (Firat \& Venkatesh, 1993). For instance, some marketing scholars consider marketing to be the ultimate social practice of postmodernity, blending art and commerce and requiring the constant renewal of styles, forms and images. Once considered to be a fad by some members of many academic disciplines (Firat \& Schultz, 1997), postmodernism could prove to be a serious candidate as a new perspective to view and appreciate design thinking.

In comparison to sociology, political science, marketing and management, design discipline has been relatively slow to recognize the presence and influence of postmodernism. However, recently, a number of design scholars have begun to explore the postmodernist implications. Yet our literature review indicates that there is still a dearth of attention and investigation by design scholars in regards to the relationship between postmodernism and design thinking.

Our objective, then, is to foster the discourse on the link between postmodern organization and design thinking, and in turn, to suggest strategic ramifications for design managers and investigation opportunities for management scholars.

\section{Postmodernism}

It is difficult, to define this phenomenon precisely in just a few sentences, since it continues to evolve. Instead, it might be more important to focus on what it claims to avoid - the modernist project. Postmodernism was originally a reaction to modernism, which is identified with rationality, linearity (in time, in progress, in forms of thinking), and "purification" (Latour, 1993, pp. 10-11). Largely influenced by the disillusionment induced by the Second World War, postmodernism tends to refer to a cultural, intellectual, or artistic state lacking a clear central hierarchy, linearity or organizing principle and embodying and embracing extreme complexity, contradiction, ambiguity, diversity, and interconnectedness (Firat \& Venkatesh, 1993). Some consider the 1950s to be the period when postmodern conditions that were already present in modernity began to unfold, and the 1960s to be the period when they became more pronounced (Firat \& Venkatesh, 1993). According to Lyotard "postmodern is probably a very bad term because it conveys the idea of a historical "periodization"”. 
"Periodizing", however, is still a "classic" or "modern" ideal. "Postmodern" simply indicates a mood, or better a state of mind (Lyotard, 1992).

\section{Postmodernism, Social Constructivism and Design Thinking}

Postmodern school of thought claims that human beings are more complex, beyond rationality, they have feelings and life has broader meanings. Social constructivism can be seen as a source of postmodern movement, and has been influential in the field of cultural studies because the concept of socially constructed reality stresses the on-going building of worldviews by individuals in dialectical interaction with society at any time. According to this view, the numerous realities so formed comprise the imagined worlds of human social existence and activity, gradually channeled by habit into institutions supported up by language conventions, given ongoing legitimacy by mythology, religion and philosophy, maintained by socialization, and subjectively internalized by upbringing and education to become part of the identity of social citizens.

According to Berger and Luckmann (1966), "habitualized actions, retain their meaningful character for the individual although the meanings involved become embedded as routines in his general stock of knowledge, taken for granted by him and at hand for his projects into the future". Habitualization provides individual with lesser amount of choices to process and this liberates the individual from the burden of "all those decisions", bringing a psychological relief that has its basis in man's "undirected instinctual structure". The authors (1966) suggest that habitualization gives the direction and the specialization of activity and relieves the accumulation of tensions that is a consequence of undirected drives. The authors claim that appearance of a stable background in which individual may function with reduced amount of decisions to make would liberate energy and open up a platform for imagination, innovation and (design thinking) to burgeon. However, this may be difficult if the individual is embedded in a modern environment (as opposed to postmodern).

\section{Postmodern Organization}

Just imagine how good it feels to wake up every morning and really look forward to work. Imagine how good it feels to use your creativity, your skills, your talent to produce a film [...] or to edit a magazine. [...] Are you there? Does it feel good? (Department of Media, Culture and Sport/Design Council/Arts Council of England, 2001, p. 1)

Understanding postmodernism and its implications is critical, especially for organizations since postmodernism has an influence on the culture within which these organizations have to operate (Firat \& Schultz, 1997).

Contingency theory, resource-dependency theory, evolutionary theory, and institutional theory show us that organizations are dependent on, interrelated with, and continuously interacting with their surrounding environment. Organization's activities, structures, and processes are affected when the organization's environment becomes more turbulent, elusive, unpredictable, or complex (Styhre, 2001).

While modernity is characterized by the belief in the qualities of stability, homogeneity, predictability, and control, postmodern society is characterized by heterogeneity, change, ruptures, fluxes, breaks, bifurcations and turns (Best \& Kellner, 1997, 2001). Styhre (2001) suggests that "the complexity theory underscores the differences between, on the one hand, the small and somewhat overrated realm of predictability and control and, on the other hand, the vast domains of complex, chaotic, unpredictable, and elusive processes and changes" (e.g., 
Brown \& Eisenhardt, 1998; Anderson, 1999). Complexity theory has refocused attention to qualities of reality that have been treated as substantially insignificant in the modernist epistemology (Prigogine \& Stengers, 1984; Cillier, 1998). Reality is no longer the protected and well-organized domain wherein organizations provide a specific purpose, but reality turns into the combination of what is within the control of individual and what is still beyond full understanding and control (Serres, 1982, 1995). This new approach to reality brings a need for a reconceptualization of our established view of organizations, leadership, careers, communication, and so forth (Styhre, 2001; Spender, 1998).

Instead of promoting stability and control, postmodern writers emphasize movement, change, and elimination of boundaries between entities, and processes, and novelty. Postmodernity has introduced skepticism toward the meta-narratives of truth, progress, univocal understanding, and finality (Lyotard, 1979, 1984; Best \& Kellner, 1997). Feminists, postcolonial thinkers, and "anti-humanists" such as Foucault (1980), Heidegger and Nietzsche questioned the meta narratives of modernity. In addition, the rise of a complexity theory that adds insights from the sciences to the postmodern critique of modernity enables a radical critique of the notion of the organization. Best and Kellner (1997, p. 224) wrote:

Postmodern science turns away from absolute certainty, rejects notions of fixed, immutable orders and absolute truths in favor of conceptions of evolving complexity and probability. It breaks away from mechanism and machine metaphors and affirms organism and biological models, and thus shifts from a self-contained and immutable universe to an open, self-organizing, dynamic cosmos that is constantly changing and evolving.

Initially, postmodern form of organization has been pronounced as an alternative to bureaucratic organization. Peter Drucker was the first to apply the term "postmodern" to organization, in his book titled, Landmarks of Tomorrow. To Drucker, postmodern meant a move away from the Cartesian universe of mechanical cause/effect (subject/object duality) to a new universe of pattern, purpose, and process. This kind of organizations is now described as "loosely coupled, fluid, organic, and adhocratic instead of the static bureaucratic structures that traditional organization literature have covered" (Boje, 2001).

\section{Characteristics of Postmodern Management}

In their book, Managing in the Postmodern World, Boje and Dennehy (2000) mention five main characteristics of postmodern management: First, postmodernism encourages multidisciplinary research and enables linking management theorizing to general theories of cultural organization. It also creates basis for use of new and more advanced qualitative methods for data collection such as story analysis, representation, namely methods which can complement present applications of qualitative research on management. Second, by emphasizing cultural knowledge, context and nature of social organization, postmodern reshapes the management and organization landscape. Postmodern moves research away from the organization or individual as a unit of analysis, examines organizations in their societal and cultural context. As such, postmodernism provides an integrative framework for understanding management and organization. According to Boje and Dennehy (2000), instead of specialized, tree-of-knowledge, divisions of knowledge, "postmodernism brings a rhizomatic approach (Chia, 1999), where a rhizome forms inter-connections among the roots of a tree, rather than the pattern of separated and specialized branches". Third, to critical postmodernists, organizations play important activist roles in the crises of advanced capitalist society. By adopting a postmodern view, individuals may engage 
in addressing organizationally based social problems which are not often addressed in a holistic manner in the management literatures. Fourth, postmodern management borrows perspectives from various areas outside the centre of traditional management research — sociology, psychology, industrial psychology, social anthropology, rhetoric, literary criticism, history, etc.. Finally, a deeper understanding of postmodernism enables the development of theories of the management of social and organizational change. The "humanization" of the social landscape of organizations would help overcome or solve the critical problems faced by today's organizations.

\section{Design}

Design's power runs far deeper than aesthetics... If you are mapping out a sales strategy, or streamlining a manufacturing operation, or crafting a new system for innovating you are engaged in the practice of design. (Bill Breen, Masters of Design, 2004)

With limited available literature, there is not a set definition of design and the activities it involves. However, this is not surprising for an emerging field of investigation as "consensus among researchers can be reached only when theories converge into consolidated paradigms" (Calabretta, Montaña, \& Moll, 2006; Kuhn, 1996). As a young field of research, the growing number of articles published in academic journals and discussed in conferences is promoting this discipline which has been confused with engineering over the years and the design research community is finally claiming its autonomy (Calabretta, Montaña, \& Iglesias, 2008).

Herbert Simon, in the Sciences of the Artificial (MIT Press, 1969, p. 55) refers to "design" as the "transformation of existing conditions into preferred ones".

In the domain of marketing, according to Kotler and Rath (1984), "Design (management) is the process of seeking to optimize consumer satisfaction and company profitability through the creative use of major design elements (performance, quality, durability, appearance, and cost) in connection with products, environments, information, and corporate identities".

According to Industrial Design Society of America, industrial design (ID) is the professional service of creating and developing concepts and specifications that optimize the function, value and appearance of products and systems for the mutual benefit of both user and manufacturer. Industrial designers develop these concepts and specifications through collection, analysis and synthesis of data guided by the special requirements of the client or manufacturer. They are trained to prepare clear and concise recommendations through drawings, models and verbal descriptions.

Industrial design services are often provided within the context of cooperative working relationships with other members of a development group. Typical groups include management, marketing, anthropologists, psychologists, engineering and manufacturing specialists. The industrial designer expresses concepts that embody all relevant design criteria determined by the group.

The designer's unique contribution places emphasis on those aspects of the product, service or system that relate most directly to human characteristics, needs and interests. This contribution requires specialized understanding of visual, tactile, safety and convenience criteria, with concern for the user. Education and experience in anticipating psychological, physiological and sociological factors that influence and are perceived by the user are essential industrial design resources. 


\section{Design Thinking}

What now matters is the design and delivery of value. That needs design thinking. That needs creative thinking. Judgment thinking alone is not going to be enough. Most people, in business and elsewhere, have done very well on judgment thinking. Such people are rarely aware of the need for "design thinking". They find it difficult to conceive that there is a whole other aspect of thinking that is different from judgment thinking. It is not that such people are complacent. It is simply that they do not know that there is another aspect to thinking. (Edward de Bono, 2003)

As with design, there's probably no one definition of design thinking everyone would agree on. What distinguishes designers is what Diego Rodriguez (2007) calls "design thinking" which is analytic thinking complemented with the unique way that designers think. Design thinking is evidence-driven, includes holistic thinking with an integrative view, emphasizes experimentation, and permits intuitive thinking and optimism.

To David Burney (2007), design thinking is a term to define a way of thinking that produces transformative innovation.

While the term feels trendy, the way of thinking is hardly new. One can think of the cave painters in Lascaux 25,000 years ago as design thinkers - they first began to collect data about the world they experienced, express that data by creating visual stories, document those stories in a way that could be shared into the future, and use that data to create new and innovative ways to solve their problems. The creation of alphabets thousands of years later is an example of design thinking.

As such, design thinking can be attributed to an improved future. Unlike critical thinking, which is a process of analysis and is associated with the deconstruction of ideas, design thinking is a creative process based around the construction of ideas. Not allowing judgments, design thinking eliminates the fear of failure and encourages maximum input and participation. Non-routine, out-of-box ideas are welcome, since these often pave the way for the most creative solutions. Every individual is designer, and design thinking is a process of applying design methodologies to miscellaneous life situations.

Roger Martin (2006) sees design thinking as the source of next competitive advantage. He distinguishes between two fundamental kinds of thinking which co-exist and often collide in business organizations: analytical thinking and design thinking.

Along the same lines, Cagan and Vogel (2002) make distinction between the way engineers and designers think. Their research findings indicate that for the designers, shape and aesthetics drive the design process whereas for the engineers, cost and complexity drive the process. Cagan and Vogel call these differences in perception as "perceptual gaps". Perceptual gaps are the differences in perspectives that team members have that stem from discipline-specific thinking and prevent teams from developing an integrated interests-based conflict resolution process.

Cagan and Vogel's (2002) research identifies several causes of perceptual gaps. One can be attributed to differences in education. "Engineers are trained to know what is 'right". They use physics and math to model, understand, and eventually control their environment. They recognize what can be done and what can't be done, based on their understanding of how the world works. They think in terms of function where form is often secondary. They focus on performance, quality and manufacturing. Designers on the other hand, are primarily visual thinkers, trained to explore and think about what should be, not what is. They are limited only by their imagination and influenced by the human side of the world around them. They have a good understanding of manufacturing but are comfortable pushing the limits if doing so allows them to better express their forms. Their 
understanding of quality is about aesthetics, playfulness, being surprising and addressing to emotions.

Bearing in mind our project of locating design thinking in the postmodern organization, and considering all the complementary descriptions above, we define design thinking as a distinctive process of mind which manifests itself in shape, configuration or composition of pattern or color containing performance (functionality), image (aesthetics, look, feel) and style (a manner of doing things, especially in a fashionable way) to produce a product, process, service, user experience, or an organic change.

Does design thinking matter?

In 1960, Herbert Simon, the Nobel Prize winning economist who also had considerable contributions in the area of cognitive psychology, computer science and robotics, predicted that while routine factory and clerical work would be automated, new work world be created in the fields of management, innovation, and design. Robert Reich later emphasized the role of "symbolic analysts" who think and manipulate symbols for a living (Florida, 2005).

A series of gradual changes in the US economy and society introduced a new system of working and living in recent decades. According to Florida (2005):

We are entering the creative age because it is the prime mover of US economy. More people than ever before are getting to do creative work for a living. The number of people in highly creative occupations - from architects to aesthetic workers, engineers and scientists to artists and writers, high-end managers, planners and analysts to healthcare- climbed dramatically in the twentieth century. In 1900, creative workers made up only about 10 percent of the U.S. workforce. By 1980, that figure had risen to nearly 20 percent. Today, almost 40 million workers - some 30 percent of the workforce - are employed in the creative sector... However, US society is engaging only a small percentage of the potential creative capital by doing a relatively poor job of motivating this 30 percent of the workforce in the creative sector.

The real issue is how much creativity employers actually tap in their organizations. Florida (2005) highlights that, "while more than three-quarters of high-tech elite workers said their jobs require a 'lot of creativity', less than half said that their bosses were supportive of them being 'creative on the job' (Florida, 2005). It almost sounds like organizations are designed to be not creative.

However, the distinctive nature of "design thinking" can be a significant differentiator among competing organizations, processes, products or services, though, so far, nobody has focused on the general question of how design thinking could be capable of generating sustainable competitive advantage. In other words, there are no academic studies analyzing what kind of managerial practices, values, and assumptions are more likely to be associated with an appropriate management of the design (thinking) (Calabretta \& Montaña, 2006).

Research on design thinking indicates that there is lack of academic study on the general questions of what kind of firms is effectively able to develop a design function capable to generate sustainable competitive advantage and what kind of managerial practices, values, and assumptions are more likely to be associated with an appropriate management of design. The limited research which identifies culture as a major barrier to greater design (thinking), points out that the only way for overcoming this limitation is to have (design thinking) already integrated in corporate culture and to cultivate this "amalgamation" from the very start (Calabretta et al., 2008; Filson \& Lewis, 2000; Beverland, 2005).

\section{Postmodernity and Design Thinking}

Imagination is the living power and prime agent of all human perception. (Samuel Taylor Coleridge) 
According to Albert Einstein, imagination is more important than knowledge. "Innovation does not come magically from an invisible hand, great advances have always sprung from ideas. Ideas don't fall from the sky, they come from people. People design the products, services, experiences" (Florida, 2006), but people and their ideas cannot be abstracted from the environment they are in.

Design thinking, which pushes knowledge forward and creates new possibilities through imagination, needs the postmodern organization to flourish. Martin (2004) cautions that as organizations grow, analytical thinking often crowds out design thinking. He also suggests that to benefit from design thinking, an organization would need to understand how analytical thinking and design thinking differ, why and how they come into conflict, and how to create a culture which appreciates and encourages design thinking. Postmodern organizations which foster diversity/tolerance, promote creativity, cultivate imagination, encourage collaboration and reward intrinsic motivation may achieve creation of such a culture and would benefit from working with design think-tankers such as IDEO, a design consulting company which can be considered as "postmodern".

\section{Managerial Implications}

"Even though design is a potent strategic tool that companies can use to gain sustainable competitive advantage, companies neglect design as a strategy tool" (Kotler \& Rath, 1984). Kotler and Rath's assertion was accurate, however, it has been more than 20 years and still there is little academic and managerial research has

been done on the strategic view of design. Traditionally, companies have considered design as a complementary aspect of new product development, rather than as a strategic resource for generating competitive advantage. Consequently researchers have rarely devoted their attention to the role (Calabretta \& Montaña, 2006). But now things are changing and design is becoming a popular topic in the business world today as a source of competitive advantage. In 2006, World Economic Forum featured a "roster of programs on new thinking about innovation and the value of design as a means of unlocking breakthrough ideas" (Fraser, 2006).

Emerging developments in the use of design and design thinking can lead to innovation in services and customer experience. Well-managed design (thinking) has the power to build brand value, harness innovation, shape strategy, and attain customer satisfaction (Calabretta, 2006). As the intense competition urges firms to be closer to their customers, design thinking becomes more important. "During this shift from the economics of scale to the economics of scope and choice and as mass markets fragment and brand loyalty disappears, corporations are more involved in improving "consumer experience"” (Nussbaum, 2004).

According to Fraser (2006), inspiration must be translated into implementation. Perhaps one of the best ways to understand how to convert design thinking into "design doing", is to look into the industry practices by IDEO. As a design consulting company which we may consider as "postmodern", IDEO has transferred its ability to create consumer products into designing consumer experiences in services, from shopping and banking to health care and wireless communication. However, by showing global corporations how to change their organizations to focus on the consumer, over the years IDEO has transformed itself from a design company to innovation service provider. "IDEO showed us that we are designing human experiences, not buildings... Consulting firms usually come in, go away, and return with heavy binders that sit on the desk. With IDEO, we partner up and work side-by-side. We are internalizing their methodology to build our own culture of innovation" says Adam D. Nemer, medical operations services manager at Kaiser (Nussbaum, 2004). 
While the business consultants tend to look at the corporate world through a cut and dry business-school perspective, by contrast, IDEO advises clients by teaching them about the consumer world through the eyes of anthropologists, sociologists, graphic designers, engineers, and psychologists. "I haven't seen anything like them before", says Tom Wyatt, president of Warnaco's Intimate Apparel Group, who is turning to IDEO to help battle rival Victoria's Secret Ltd. "They're creative and strategic, eclectic and passionate". Some of IDEO clients understand the fact that the culture change is fundamental to design thinking. For instance Procter and gamble has teamed up with IDEO to create a more innovative culture. IDEO challenges the corporate culture using unusual techniques to energize corporate clients such as "body storming", "behavioral mapping", "quick and dirty prototyping”, "deep dives", "unfocus groups", "shadowing”, and "be your customer", or recruiting people with two or three advanced degrees who climb mountains, go birding in the Amazon, and bike through the Alps. The head of the IDEO group that teaches companies how to innovate is a graduate of the U.S. Naval Academy with a BA in history and a master's degree in architecture (Nussbaum, 2004).

Some corporations send their top people to IDEO just to open their minds.

P\&G CEO Lafley took all the people who report directly to him-his entire Global Leadership Council of 40 business-unit heads - to San Francisco for a one-day immersion. IDEO promptly sent them all out shopping. The goal was to have the execs understand consumer experiences so they could come up with innovations. Lafley's own team went to buy music, first at a small, funky music store, then at a large retail music store, and finally online. IDEO team members shopped alongside them to analyze each experience as it unfolded. Other $\mathrm{P} \& \mathrm{G}$ executives went shopping with poor people so they might better understand what it means for Third World consumers to buy the company's products. (Nussbaum, 2004)

\section{Conclusion}

Design thinking is a powerful tool which pushes knowledge forward and creates new possibilities through imagination. However, in order for design thinking's growth, it requires a corporate culture where the postmodern organization can bloom. During the transformation process, organizations should be very careful about what Martin (2004) warns as analytical thinking's crowding out design thinking. In order to be able to handle this transformation challenge, an organization would need to understand how analytical thinking and design thinking differ, why and how they come into conflict, and how a culture which appreciates and encourages design thinking can be created. Postmodern organizations which nurture diversity and tolerance, promote creativity, cultivate imagination, encourage collaboration and reward intrinsic motivation may achieve creation of such a culture to embrace and deploy design thinking.

\section{References}

Anderson, P. (1999). Complexity theory and organization science. Organization Science, 10(3), 216-232.

Berger, P. L., \& Luckmann, T. (1966). The social construction of reality: A treatise on the sociology of knowledge (pp. 51-55, 59-61). Garden City, New York: Anchor Books.

Best. S., \& Kellner, D. (1997). The postmodern turn. New York: Guilford Press.

Best. S., \& Kellner, D. (2001). The postmodern adventure: Science, technology, and cultural studies at the third millennium. London \& New York: Routledge.

Beverland, M. B. (2005). Managing the design innovation-brand marketing interface: resolving the tension between artistic creation and commercial imperatives. Journal of Product Innovation Management, 22, 193-207.

Boje, D.M. (2001). Narrative methods for organizational and communication research. London: Sage.

Boje, D. M., \& Dennehy, R. (Eds.). (2000). Managing in a postmodern world. London: Sage.

Brown, S. L., \& Eisenhardt, K. M. (1998). Competing on the edge. Boston: Harvard University Press. 
Burney, D. (2007). What is design thinking? Retrieved from http://www.redhat.com/magazine/019may06/features/burney/

Calabretta, G., \& Montaña, J. (2006). A description of the design management process: Involved activities and enabling conditions. EURAM 2006: The European Academy of Management Annual Conference. Oslo, Norway.

Calabretta, G., Montaña, J., \& Iglesias, O. (2008, March). A cross-cultural assessment of leading values in design-oriented companies. Cross Cultural Management Journal.

Chia, R. (1999). A "rhizomatic" model of organizational change and transformation: Perspective from a metaphysics of change. British Journal of Management, 10, 209-227.

Dholakia, N., \& Firat, A. F. (2006). Global business beyond modernity. Critical Perspectives on International Business, 2(2).

Drucker, P. (1999, October). Beyond the information revolution. Atlantic Monthly, 284, 47-57.

Filson, A., \& Lewis, A. (2000). Barriers between design and business strategy. Design Management Journal, Fall, 48-52.

Firat, A. F. (1992). Postmodernism and the marketing organization. Journal of Organizational Change Management, 5(1), $79-83$.

Firat, A. F., \& Venkatesh, A. (1993). Postmodernity: The age of marketing. International Journal of Research in Marketing, 10(3), 227-49.

Firat, A. F., \& Venkatesh, A. (1995). Liberatory postmodernism and the reenchantment of consumption. Journal of Consumer Research, 22, 239-267.

Firat, A. F., Dholakia, N., \& Venkatesh, A. (1995). Marketing in a postmodern world. European Journal of Marketing, 29(1), 40-56.

Firat, A. F., Shultz, II., \& Clifford, J. (1997). From segmentation to fragmentation. European Journal of Marketing, 31(3/4).

Florida, R. (2005). The flight of the creative class. The new global competition for talent. Harper Business, Harper Collins.

Foucault, M. (1980), Power/knowledge: Selected interviews and other writings (C. Gordon, Ed.). New York, N.Y.: Pantheon Books.

Fraser, H. (2006). Turning design thinking into design doing. Rotman Magazine, Spring/summer.

Gergen, K. (1989). Organisational theory in the postmodern era. New Directions in Organization Theory and Analysis. London: Sage.

Kotler, P., \& Rath, G. A. (1984). Design: A powerful but neglected strategic tool. The Journal of Business Strategy, $5(2), 16$.

Kuhn, T. S. (1962). The structure of scientific revolutions. Chicago: University of Chicago Press.

Latour, B. (1993). We have never been modern. Cambridge Mass., USA: Harvard University Press.

Lyotard, J. F. (1979/1984). The postmodern condition: A report on knowledge. Manchester: Manchester University Press.

Lyotard, J. F. (1992). The postmodern explained. Minneapolis, MN: University of Minnesota Press.

Martin, R. (2004). The design of business. Rotman Magazine, Winter.

Nausbaum, B. (2004, May 17). The power of design. Business Week Cover Story.

Parker, M. (1992). Post-modern organizations or postmodern organization theory? Organization Studies, 13(1).

Prigogine, I., \& Stengers, I. (1984). Order out of chaos: Man's new dialogue with nature. New York: Bantam Books.

Sauquet, A. (2008, March, 7). The art center_global dialogues: Disruptive thinking. Barcelona, Spain.

Serres, M. (1982/1995). Genesis. Ann Arbor: University of Michigan Press.

Simon, H. A. (1969). The sciences of the artificial (1st ed.). MIT Press.

Spender, J. C. (1998). Pluralist epistemology and the knowledge-based theory of the firm. Organization, 5(2), 233-256.

Styhre, A. (2001). Nomadic organization: The postmodern organization of becoming. Journal of Critical Postmodern Organization Science. 